\title{
ニューラルネットワークを用いた適応型フィードフォワード フィードバックコントローラ
}

\author{
山田孝 行*・藪 田哲 郎*
}

\author{
Adaptive Type Feedforward Feedback Controller Using Neural Networks
}

Takayuki YAMADA* and Tetsuro YABUTA*

There have been many studies on the application of neural networks to servo controllers in order to design flexible controllers which have nonlinear mapping capabilities. Most of them are studies on series controllers which use the neural network output as the object plant input. Only M. Kawato has proposed a paralled controller which uses both the neural network output and the conventional control output as the object plant input. However, his proposed controller is analog rather than digital. The stability of a digital controller is different from that of an analog controller. We should investigate digital controller stability in order to construct a neural network servo controller which uses software.

Therefore, this paper proposes an adaptive type feedforward feedback controller which uses a neural network. The proposed controller is a parallel type controller. It is designed for digital control systems and its stability condition is investigated. Simulated results for a second order plant confirm both its effectiveness and characteristics.

Key Words : neural network, control, servo, nonlinear

\section{1. はじめに}

ニューラルネットワークのもつ柔軟性に着目し，口 ボットなどの制御系への応用も行われるようになってき た1) 14). また, 近年ロボットハンド, ロボットビジョン, 倒立振子などへ応用も試みられている, ${ }^{1) \sim 5)}$. これらの試 みのうちサーボレベルの制御への応用も進められてお り，種々の制御系が提案されている。これらのサーボレ ベル制御系の中でニューラルネットワークの出力を対象 プラントの入力とするタイプ(本報告では直列夕イプと 呼ぶ) は構造が比較的単純であり, Narendra, Psaltis, 山 田らにより検討されている ${ }^{6)}$. 10 . しかし, 直列型はニュー ラルネットワークのもつ基本的な問題点を検討すること には適している反面, コントローラの安定性を保証する フィードバックループ的な要素をもニューラルネット

*NTTフィールドシステム研究開発センタ 茨城県那珂郡 東海村白方白根 162

* NTT Telecommunication Field Systems R \& D Center, Naka-gun, Ibaraki

(Received July 12, 1993)

(Revised December 17, 1993)
ワークにより構成しようとするものであり，そのロバス 卜性に疑問が残る。一方, 従来の制御理論によるフィー ドバックループの出力とニューラルネットワークの出力 との和をプラントの入力とするタイプ(本報告では並列 型と呼ぶ)がある.このタイプはフィードバックループに より安定性を向上できるため, 直列型よりもロバストな コントローラを設計できる可能性がある. また, 並列型 は生物の運動制御と近いフレームワークをもつことが川 人らにより指摘されており, そのロボットの軌道制御へ の応用例も示されている ${ }^{11,12)}$. しかし, 従来検討されてい た制御系は連続時間系であり，離散時間系に対する検討 例はない：離散時間系のコントローラの安定条件は一般 的に連続時間系とは異なる。このため, 離散時間系にお ける安定条件を検討することは今後ソフトウェアによる ニューラルネットワークを用いたコントローラを設計す る上で重要な検討課題となると思われる.

そこで，本報告では並列型に属するニューラルネット ワークを用いた適応型フィードフォワードフィードバッ クコントローラを離散時間系を対象として設計した。ま た，設計したコントローラの安定性についてプラントお 
よびニューラルネットワークが線形の場合について検討 し,フィードバックループのゲインがニューラルネット ワークの重みの収束性に与える影響を明らかにした。さ らに, 2 次プラントを対象としたシミュレーションによ り，本コントローラが実現可能であることを明らかにし ている.また，先の安定解析を非線形ニューラルネット ワークを用いた場合へ拡張する一手法について考察し た.

\section{2. 連続系と離散時間系}

本章ではニューラルネットワークを用いた連続系お よび離散時間系システムについて, その学習の安定条件 .について考察し, 一般的に連続系と離散時間系の安定条 件が異なることを明らかにする。まず, 連続系について， $\mathrm{PDP} モ テ ゙ ル の$ 枠組みに従うと任意の重み $W_{i}$ の学習則 は次式のように記述することができる ${ }^{13)}$.

$$
\frac{d W_{i}}{d t}=-\eta \frac{\partial J}{\partial W_{i}}
$$

ただし， $t$ は時間， $\eta$ は学習の速さを決定するパラメー 夕, $J$ はニューラルネットワークが最小化するべき関数 であり, 本報告では評価関数と呼ぶ. この評価関数は通 常二乗誤差などの負でない実数関数が選ばれる.

ここで, 評価関数 $J$ を重み $W_{i}$ と時間 $t$ の関数とみな したとき, $J$ の時間変化は次式のように変形される.

$$
\frac{d J}{d t}=\frac{\partial J}{\partial W_{i}} \cdot \frac{d W_{i}}{d t}+\frac{\partial J}{\partial t}
$$

(1)式を (2)式に代入すると次式の結果を得る.

$$
\frac{d J}{d t}=-\eta\left(\frac{\partial J}{\partial W_{i}}\right)^{2}+\frac{\partial J}{\partial t}
$$

以下，(3)式の左辺 $\{d J / d t\}$ の符号を調べることによ り, 連続系の安定条件について考察する. (3) 式に示す ように右辺第 1 項 $\left\{-\eta\left(\partial J / \partial W_{i}\right)^{2}\right\}$ は $\eta$ が正であれば時 間 $t$ に関わりなく負となる。もし, 制御系の特性が $\{\partial J / \partial t$ $\leqq 0\}$ であれば，（3)式から明らかなように，評価関数の 時間変化量 $(d J / d t)$ は常に負または 0 であり, 学習は安 定である。また，この結果よりニューラルネットワーク をサーボレベルの制御系に応用した場合, ニューラル ネットワークの重みの学習の安定性は $\{\partial J / \partial t \leqq 0\}$ であれ ば,プラントのダイナミクスに依存しない.さらに, クが 負でなければ未知の受動的な非線形プラントに対しても コントローラは常に安定である.また, $\eta$ が大きくなるほ ど評価関数 $J$ の減少量は大きくなるので学習の収束は速 くなり，その大きさに上限はない. つぎに, $\{\partial J / \partial t\}$ の符 号の影響について考察する. $\{\partial J / \partial t\}$ の符号はプラント, コントローラおよび評価関数 $J$ の定義に依存する。この ため, $\{\partial J / \partial t \leqq 0\}$ なる条件を一般的に未知非線形プラン
トについて明らかにすることは非常に困難であると思わ れる.しかし，(3)式の左辺 $\{d J / d t\}$ は $\left\{-\eta\left(\partial J / \partial W_{i}\right)^{2}\right\}$ と $\{\partial J / \partial t\}$ の和により表わされるので, 第 2 項 $\{\partial J / \partial t\}$ がも し正であったとしても, 第 1 項 $\left\{-\eta\left(\partial J / \partial W_{i}\right)^{2}\right\}$ の值が負 でかつその絶対値が $\{\partial J / \partial t\}$ の絶対值よりも大きければ, 左辺 $\{d J / d t\}$ は負となり, 制御系は安定である.いい換え

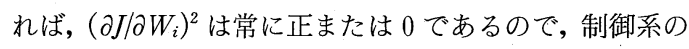
安定性を満たす $\eta$ はある下限をもつことになる。また， この場合にはクが大きいほど評価関数 $J$ の減少量は大

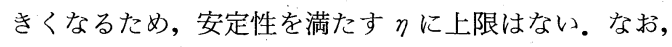
$\left\{\partial J / \partial W_{i}=0\right\}$ かつ $\{\partial J / \partial t \leqq 0\}$ のときには任意の正の $\eta に$ ついて安定であり, $\left\{\partial J / \partial W_{i}=0\right\}$ かつ $\{\partial J / \partial t>0\}$ のとき には安定性を満たす $\eta$ は存在しない.この安定条件はつ ぎに述べる離散時間系における安定条件とは明らかに異 なるものである.

以下, 離散時間系について同様の議論を行い安定条件 が連続系と異なることを示す．離散時間の場合の学習則 を次式で定義する。

$$
W_{i}(P+1)=W_{i}(P)-\eta \frac{\partial J(P)}{\partial W_{i}(P)}
$$

ただし， $P$ は各試行ごとに重みを変更する場合は試行回 数, 各サンプリングごとに変更する場合はサンプリング 数である.（4)式より重みの変化量 $\Delta W_{i}$ は次式となる.

$$
\Delta W_{i}=W_{i}(P+1)-W_{i}(P)=-\eta \frac{\partial J(P)}{\partial W_{i}(P)}
$$

一方（4)式により修正された重みによる評価関数 $J$ の 変化量 $\Delta J$ は $(5)$ 式より次式のように表わされる.

$$
\begin{aligned}
\Delta J & =J(P+1)-J(P) \\
& =\left(W_{i}(P+1)-W_{i}(P)\right) \cdot \frac{J(P+1)-J(P)}{W_{i}(P+1)-W_{i}(P)} \\
& =-\eta \frac{\partial J(P)}{\partial W_{i}(P)} \cdot \frac{J(P+1)-J(P)}{W_{i}(P+1)-W_{i}(P)}
\end{aligned}
$$

(6)式より学習係数 $\eta$ が負でない実数でかつ( 7 )式の 条件が満たされるとき， $\Delta J$ は $(8)$ 式のように表わされ る.

$$
\begin{aligned}
& \frac{\partial J(P)}{\partial W_{i}(P)} \fallingdotseq \frac{J(P+1)-J(P)}{W_{i}(P+1)-W_{i}(P)} \\
& \Delta J=-\eta\left(\frac{\partial J(P)}{\partial W_{i}(P)}\right)^{2} \leqq 0
\end{aligned}
$$

(8)式より，クが非負でありかつ（7)式の条件が満たさ れるとき, 評価関数の変化は常に負または 0 になり, ニューラルネットワークの重みの学習は安定であること がわかる.（8)式を満足する条件として（7) 式を必要と した理由の一つは, 離散時間系において最急降下法を近 似的にしか表現できないからだと思われる。

ここで，（7) 式の右辺は評価関数 $J$ の重み $W_{i}$ に関す る偏微分を差分近似した形であることがわかる.このこ 
とから学習係数 $\eta$ が比較的大きいとき (7)式は成立し なくなることが予想される。よって，ニューラルネット ワークの重みの学習の安定性を保証する学習係数 $\eta に$ はある上限が存在する。この結果は先に示した連続時間 系の安定条件とは明らかに異なる。ようて, 離散時間系 のプラントを対象としたニューラルネットワークを用い たコントローラを設計する場合，その安定条件を検討す ることは重要である。

\section{3. ニューラルネットワークを用いたコントローラ}

本章では，本報告で取り扱うフィードフォワード ·フィードバックコントローラの位置付けを明確にするた めに, ニューラルネットワークを用いた制御系の学習の 行い方およびプラントの入力の観点から分類した。

ニューラルネットワークの重みの学習の行い方によ り，コントローラを適応型と学習型に分類することがで きる ${ }^{14)}$. 軌道制御に応用した場合について, Fig. 1 に適応 型の概念図, Fig. 2 に学習型の概念図をそれぞれ示す.適 応型は図に示すようにあるサンプリング間隔ごとに ニューラルネットワークの重みの修正を行うタイプであ り，1 試行内に学習は収束する:このタイプでは, ある サンプリング間隔で重みの修正を行うために，プラント のダイナミクスがコントローラの特性に強い影響を及ぼ し，特にむだ時間の影響は顕著となる。また，離散時間 系ではむだ時間は必ず含まれるため,この問題を避けて 通ることはできない.

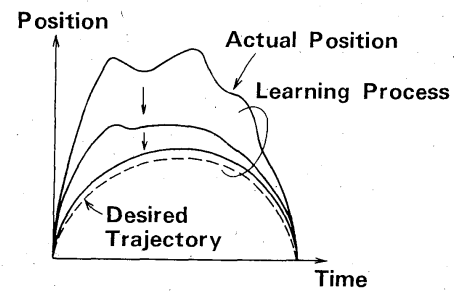

Fig. 1 Scheme of learning type

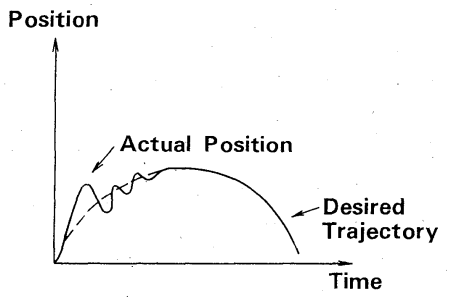

Fig. 2 Scheme of adaptive type
学習型は Fig. 2 に示すように，ある試行間隔でニュー ラルネットワークの重みの学習を行い, ある試行の後に 学習は収束する。このため, 学習が収束するまでの時間 は適応型に比べ長くなる。また，このタイプでは 1 試行 内では重みの更新を行わないため，プラントのダイナミ クスの影響は適応型に比べ小さくなると予想される。ま た，各試行間において十分な計算時間を取ることができ るため, 適応型に比べより複雑な制御系が実現できる可 能性があり，最適制御系などの実現の可能性も山田らに より示されている ${ }^{15)}$.これらの適応抢よび学習型は以下 に概説する直列，並列およびセルフチューニングタイプ のそれぞれについて定義することができる.

つぎに，プラントの入力の観点からニューラルネット ワークを用いたコントローラの分類を行う．Fig. 3 に直 列型の概念図を示す．直列型はニューラルネットワーク の出力をそのままプラントの入力するタイプである.ま た, 構造が最も単純なため, ニューラルネットワークを 用いたコントローラの基本特性を検討する上で適してい る.このタイプについては Naredra, D. Psaltis および山 田らにより検討されているが6) 10)，フィードバックルー プ的な要素をもニューラルネットワークにより構築しよ うとしているため，ロバストを向上するためにはほかの 手法を併用する必要があるのではないかと思われる。

Fig. 4 に並列型の概念図を示す。並列型はニューラル ネットワークの出力と従来の制御との和をプラントの入 力とする.このタイプは学習初期の安定性を従来の制御 則によって保証し，学習が進むにつれてニューラルネッ トワークのみにより制御を行うことを目的としている. このため, 川人らによる検討例では従来の制御則の出力 を 0 にするようにニューラルネットワークの学習が行わ れる11 12).このタイプについては川人らにより大脳生理 学の知見に基づく設計が有名である. しかし, 彼らの対 象とするプラントは連続時間系で記述される単純な力学 系であり，離散時間系についての検討はない。しかし，

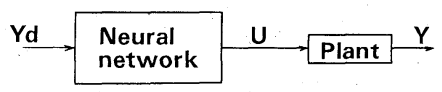

Fig. 3 Scheme of series type

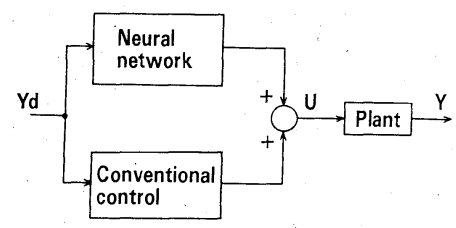

Fig. 4 Scheme of parallel type 
山田・藪田：適応型フィードフォワードフィードバックニューラルネットコントローラ

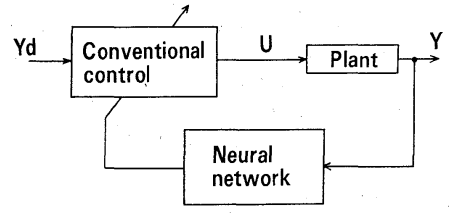

Fig. 5 Scheme of self-tuning type

前章で述べたように離散時間系でのニューラルネット ワークの特性は一般的に連続時間系とは異なる。このた め, ソフトウェアでコントローラを実現しようとする場 合には必然的に離散時間系となるため, 離散時間特有の 特性の検討が必要である.

直列型と並列型以外に Fig. 5 に示すセルフチューニ ングタイプのコントローラも考えることができる.この タイプはニューラルネットワークにより, 従来の制御系 のパラメータを調整しようとするものであり, 理想的な フィードバックゲインを教師信号とする設計例が福田, 鵫田らにより報告されている ${ }^{16)}$.一方, 山田らは, 教師信 号として制御の目標值を用いるセルフチューニングコン トローラを提案している17).

本報告では, 以上述べた制御系のうち並列型に属する 離散時間系を対象とした適応型フィードフォワード フィードバックコントローラについて検討した。また, 2 章に述べたように離散時間系の安定条件は連続時間系 と異なるため, 設計したコントローラについてプラント およびニューラルネットワークが線形のときの安定条件 について検討した。

\section{4. 適応型フィードフォワードフィードバックコン トローラの設計}

フィードフォワードフィードバックコントローラはプ ラントの入力を従来の制御則によるフィードバックルー プの出力およびニューラルネットワークの出力との和と し，学習をフィードバックループの出力を 0 にするよう に行うコントローラである.よって，ニューラルネット ワークの入力および学習則を具体的に示せばフィード フォワードフィードバックコントローラを実現すること ができる、そこで，本章ではニューラルネットワークの 入力ベクトルを定義し，この入力を用いれば対象のプラ ントが線形のときフィードバックループの出力を 0 にす るような重みの存在することを明らかにする. また，学 習則についてはプラントのむだ時間を考慮した学習則を 定義した. 定義した学習則の安定条件については次章で 議論する。

本報告で述べるコントローラはフィードフォワード フィードバックコントローラであるが, ダイレクトコン
トローラと同様に安定性はプラントのダイナミクスと 密接に関連する ${ }^{10)}$.このため, プラントのダイナミックを 何らかの形で安定化し, 議論する必要がある.このため, 本報告では対象とするプラントは線形部が支配的な離散 時間 1 入力 1 出力系であるとし, その線形部の伝達関数 を(9)式で示す形で定式化する.また，ニューラルネッ 卜は三層構造の PDPタイプとし，ネット内でのフィー ドバックループおよび入力層から出力層への直接の結合 はない. また, 出力層は 1 個のニューロンにより構成し ている.

$$
\begin{aligned}
& A\left(z^{-1}\right) Y(k)=z^{-d} G_{0} B\left(z^{-1}\right) U(k) \\
& A\left(z^{-1}\right)=1+\sum_{i=1}^{n} a_{i} z^{-i}, B\left(z^{-1}\right)=1+\sum_{i=1}^{m} b_{i} z^{-i}
\end{aligned}
$$

ただし， $Y$ はプラントの出力, $U$ はプラントの入力, $G_{0}$ はプラントのゲイン, $d$ はむだ時間, $n$ および $m$ はプ ラントの次数, $a_{i}$ および $b_{i}$ は末知パラメータである. 対 象とするプラントの線形部は以下に示す前提条件を満た しているものとする.

(前提条件)

(i) プラントの次数の上限 $n, m$ は既知.

（ii）むだ時間 $d$ は既知，ただし $d \geqq 1$.

(iii） プラントの伝達関数の分子は安定多項式.

$(9)$ 式より出力 $Y(k)$ は次式のように表わされる.

$$
\begin{aligned}
Y(k)= & -\sum_{i=1}^{n} a_{i} Y(k-i)+G_{0}\{U(k-d) \\
& \left.+\sum_{i=1}^{m} b_{i} U(k-i-d)\right\}
\end{aligned}
$$

(10)式のプラントに対し, 非最小表現 ${ }^{18)}$ を用いるとプラ ントは(11)式のように表わされる。

$$
\begin{aligned}
Y(k+d)= & -\sum_{i=1}^{n} a_{y i} Y(k-i+1)+G_{0} \\
& \times\left\{U(k)+\sum_{i=1}^{m+d-1} b_{u i} U(k-i)\right\}
\end{aligned}
$$

(11)式のプラントについて，ニューラルネットワークへ の入力などの設計条件を以下検討する，なお，以下の議 論では単純化のためにフィードバックループは $P$ 制御 (比例制御)を用いるとして議論を進める.フィードバッ クループが $P$ 制御であるから, (11) 式より次式が成立する.

$$
\begin{aligned}
& U_{1}(k+d)= K_{P}(Y d(k+d)-Y(k+d)) \\
&= K_{P}\left[Y d(k+d)+\sum_{i=1}^{n} a_{y i} Y(k-i+1)\right. \\
&-G_{0}\left\{U_{1}(k)+\sum_{i=1}^{m+d-1} b_{u i} U_{1}(k-i)\right. \\
&\left.\left.+U_{2}(k)+\sum_{i=1}^{m+d-1} b_{u i} U_{2}(k-i)\right\}\right] \\
& U(k)=U_{1}(k)+U_{2}(k)
\end{aligned}
$$

ただし, $U_{1}$ は $P$ 制御の出力, $K_{P}$ は $P$ 制御のゲインで ある。（12)式より，ニューラルネットワークへの入力を 次式のように定義する. 
$\mathbf{1 2 3 8} 1994$ 年 10 月

$$
\begin{aligned}
I^{T}(k)=[ & Y d(k+d), Y(k), Y(k-1), \\
& \cdots, Y(k-n+1), U_{2}(k-1), \cdots, \\
& U_{2}(k-m-d+1), U_{1}(k), U_{1}(k-1), \\
& \cdots, U_{1}(k-m-d+1)
\end{aligned}
$$

ただし, $U_{2}$ はニューラルネットワークの出力である. また, 未知パラメータベクトルの定義を(14) 式に示す.

$$
\begin{aligned}
\alpha^{T}= & 1 / G_{0}\left[1, a_{y i}, \cdots, a_{y \cdot n-1},\right. \\
& -G_{0} b_{u 1}, \cdots, G_{0} b_{u . m+d-1}, \\
& \left.-G_{0},-G_{0} b_{u 1}, \cdots,-G_{0} b_{u . m+d-1}\right]
\end{aligned}
$$

また, ニューラルネットワークの重みの学㖬は次式に従 い 1 サンプリングごとに行うものとする.

$$
\begin{aligned}
& \omega(k+1)=\omega(k-d)-\eta \frac{\partial U_{1}(k)}{\partial \omega(k-d)} \\
& W(k+1)=W(k-d)-\eta \frac{\partial U_{1}(k)}{\partial W(k-d)}
\end{aligned}
$$

ただし, $W$ は入力層と中間層の間の重みにより構成され るマトリクス， $\omega$ は中間層と出力層の間の重みにより構 成されるべクトルである. (15), (16) 式の学習則はニュー ラルネットワークが線形のとき次式のように表わされ る.

$$
\omega(k+1)=\omega(k-d)+\eta U_{1}(k) W(k-d) I(k-d)
$$

$$
W(k+1)=W(k-d)+\eta U_{1}(k) \omega(k-d) I^{T}(k-d)
$$

またニューラルネットワークが線形のときネットの出 力 $U_{2}(k)$ は

$$
U_{2}(k)=\omega^{T}(k) W(k) I(k)
$$

である.このとき $U_{1}$ は (12)〜 (15) 式より以下のように 変形される。

$$
\begin{aligned}
U_{1}(k+d) & =K_{P} G_{0}\left\{\alpha^{T} I(k)-U_{2}(k)\right\} \\
& =K_{P} G_{0}\left\{\alpha^{T} I(k)-\omega^{T}(k) W(k) I(k)\right\} \\
& =K_{P} G_{0}\left(\alpha^{T}-\omega^{T}(k) W(k)\right) I(k)
\end{aligned}
$$

(20)式より, $\alpha^{T}=\omega^{T}(k) W(k)$ のとき, $U_{1}(k)=0$ となる.

(18)式より (13) 式で定義する入力ベクトル $I$ を用い ればフィードバックループの出力 $U_{1}$ を 0 とする重みが 存在することがわかる. 以下この重み近傍の安定性につ いて議論する. また, Fig. 6 にフィードバックフィード フォワードコントローラを 2 次プラント $(n=2, m=1$, $d=1)$ を適用した場合のブロック線図を示す.

\section{5. 安 定 性}

本章では，前章で設計したコントローラのパラメータ のうち次式で定義するパラメー夕誤差 $う$ 安定性を中 心に議論する。

$$
\zeta^{T}(k)=\alpha^{T}-\omega^{T}(k) W(k)
$$

とすると (20)，(21) 式より次式が成立する.

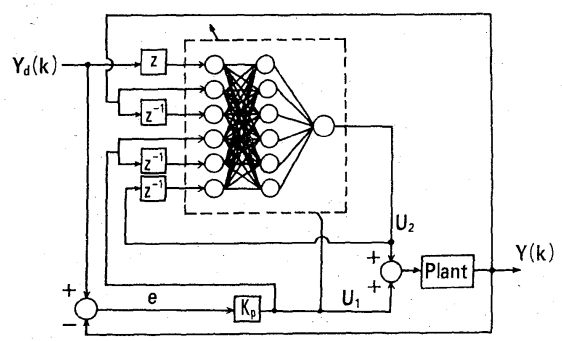

Fig. 6 Block diagram of adaptive type feedforward feedback controller

$$
U_{1}(k)=K_{P} G_{0} \zeta^{T}(k-d) I(k-d)
$$

ここで， $U_{1}^{2}(k)$ が微小だとすると (17)，(18)式より

$$
\begin{aligned}
& \omega^{T}(k+1) W(k+1) \\
& \fallingdotseq \omega^{T}(k-d) W(k-d) \\
& \quad+\eta U_{1}(k) I^{T}(k-d)\left\{\omega^{T}(k-d) \omega(k-d) \Gamma\right. \\
& \left.\quad+W^{T}(k-d) W(k-d)\right\} \\
& =\omega^{T}(k-d) W(k-d)+\eta K_{P} \zeta^{T}(k-d) \xi(k-d)
\end{aligned}
$$

$$
\xi(k)=I(k) I^{T}(k)\left\{\omega^{T}(k) \omega(k) \Gamma+W^{T}(k) W(k)\right\}
$$

となる、ただし， $\Gamma$ は単位行列である。(23)式より

$$
\begin{aligned}
\alpha^{T}- & \omega^{T}(k+1) W(k+1) \\
= & \alpha^{T}-\omega(k-d) W(k-d) \\
& -\eta K_{P} G_{0} \zeta^{T}(k-d) \xi(k-d)
\end{aligned}
$$

となり, 次式を得る.

$$
\zeta^{T}(k+1)=\zeta^{T}(k-d)\left\{\Gamma-\eta K_{P} G_{0} \xi(k-d)\right\}
$$

(24) 式より, $\left(\Gamma-\eta K_{P} G_{0} \xi(k-d)\right)$ の固有值の絶対值が 1 以下であれば，パラメー夕誤差は安定である.よって

$$
-1 \leqq \lambda\left[\Gamma-\eta K_{P} G_{0} \xi(k-d)\right] \leqq 1
$$

のとき，パラメータ誤差とは安定である.ただし， $\lambda[A]$ はマトリクス $A$ の固有值である. 以下, $\left(\Gamma-\eta K_{P} G_{0} \xi(k\right.$ $-d))$ の固有值について考察する.

$\left(\Gamma-\eta K_{P} G_{0} \xi(k-d)\right)$ の固有值 $\lambda$ は次式の関係を満た す.

$$
\operatorname{det}\left(\lambda \Gamma-\Gamma-\eta K_{P} G_{0} \xi(k-d)\right)=0
$$

(26) 式より

$$
\left.\operatorname{det}\left((\lambda-1) / \eta K_{P} G_{0}\right) \Gamma-\xi(k-d)\right)=0
$$

となる.ここで, $\xi(k-d)$ の固有値を $\lambda_{0}$ とすると (27) 式 より次式の関係を得る.

$$
\lambda_{0}=(\lambda-1) / \eta K_{P} G_{0}
$$

$\xi(k-d)$ の定義より $\xi$ のランクは 1 であるから

i ) $\lambda_{0}=0$ の固有值に対応する $\left(\Gamma-\eta K_{P} G_{0} \xi(k-d)\right)$ の固有值は(28)式より $\lambda=1$ であるから(25) 式の安 定条件は満たされる。

ii ) $\lambda_{0} \neq 0$ の固有值に対応する $\left(\Gamma-\eta K_{P} G_{0} \xi(k-d)\right)$ の固有値について (25) 式の安定条件は 
$-1 \leqq 1-\eta K_{P} G_{0} \lambda_{0} \leqq 1$

となり

$0 \leqq \eta K_{P} G_{0} \lambda_{0} \leqq 2$

のように表わされる.

以上より，(30)式を満たす実数 $\eta$ を用いればフィード フォワードフィードバックコントローラのパラメータ誤 差との漸近安定性が保証されることがわかる。また， フィードバックゲイン $K_{P}$ およびプラントのゲイン $G_{0}$ がパラメー夕誤差の安定性に関して深い関わりがあるこ とがわかる.さらに, フィードバックゲイン $K_{P}$ を小さく することにより安定性を保証する $\eta$ をきくすること も可能である.

\section{6. シミュレーション}

本報告で提案したニューラルネットを用いたフィード フォワードフィードバックコントローラが実現可能であ ることを検証するために 2 次プラントを対象としたシ ミュレーションを行った. (34)式に本シミュレーション で用いたプラントの差分方程式表現を示す。

$$
\begin{aligned}
Y(k)= & -a_{1} Y(k-1)-a_{2} Y(k-2)+U(k-1) \\
& +b U(k-2)+a_{3} Y(k-3)+C_{n o n} Y^{2}(k-2)
\end{aligned}
$$

ただし, 本シミュレーションでは, $a_{1}=-1.3, a_{2}=0.3$, $b=0.7$ である.また, ニューラルネットワークに非線形 写像能力を付加するために，次式で定義する非線形飽和 関数 (シグモイド関数)を用いた。

$$
f(x)=\frac{X g\{1-\exp (-4 x / X g)\}}{2\{1+\exp (-4 x / X g)\}}
$$

ただし， $f(x)$ は非線形飽和関数， $x$ は入力， $X g$ は非線 形飽和関数の形状を決定するパラメータである。（35）式 で表わされる関数は原点対称で原点の傾きが 1 の関数で ある.また, パラメータ $X g$ を変化させることにより，そ の形状は滑らかに線形から非線形へ変化し, $X g \rightarrow \infty$ の 時線形関数 $f(x)=x$ と等価になる. Fig. 7 にフィード フォワードフィードバック型のシミュレーション結果を

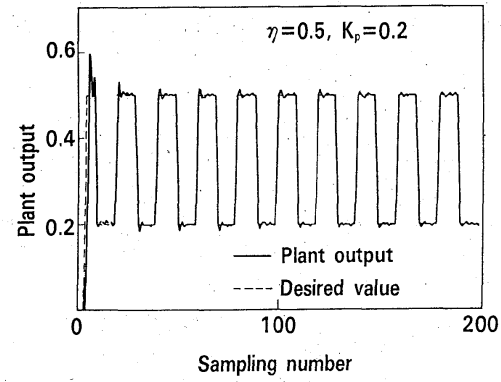

Fig. 7 Simulation result
示す.ただし $, a_{3}=0, C_{n o n}=0$ の線形プラントを対象と し，線形のニューラルネットワークを用いている. 図に 示すようにプラントの出力は学習が進むにつれて制御の 目標に収束して行くことがわかる. Fig. 8 にこのときの ニューラルネットワークの出力 $U_{1}$ とフィードバック ループの出力 $U_{2}$ を示す. 図に示すように学習が余り進 んでいないときはフィードバックループの出力 $U_{2}$ は比 較的大きいが，学習が進むにつれて小さくなり，制御の 目標值の 2 周期でほぼ 0 になっていることがわかる.

Fig. 9 にプラントに寄生要素および非線形要素が含まれ るときの学習過程を示す. $\left(a_{3}=-0.1, C_{n o n}=-0.1\right)$ た だし，このときのニューラルネットワークは非線形であ る. $(X g=20)$ 図に示すように残存誤差は残るものの寄生 要素および非線形要素を含むプラントに対しても本コン トローラは有効であることがわかる.

\section{7. 考察}

5 章では線形のプラントに線形のニューラルネット ワークを用いたときの安定性について論じたが，本章で はこの結果を非線形飽和関数を用いたニューラルネット ワークの場合について拡張する一手法について考察す る.

非線形飽和関数を用いたときの学習則は (15)，(16) 式 に示すとおりであるが，(35)式に示した非線形飽和関数

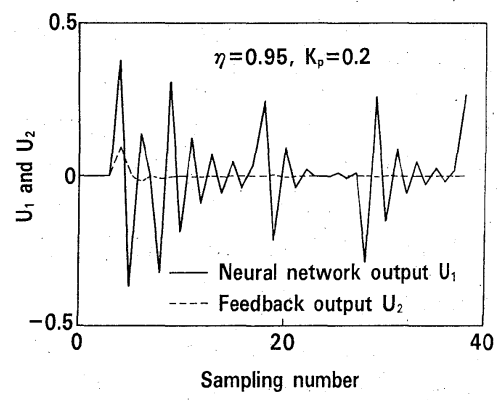

Fig. 8 Neural network output and feedback loop output

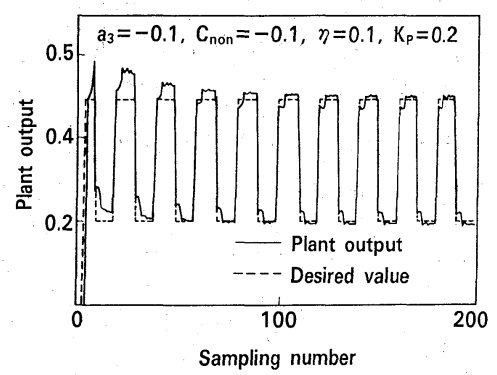

Fig. 9 Learning process for nonlinear plant 
の特性より，(15)，(16)式を以下のように書き下すこと ができる.

$$
\begin{aligned}
\omega(k+1)= & \omega(k-d) \\
& +\eta U_{1}(k) M_{1}(k-d) W(k-d) I(k-d)
\end{aligned}
$$

$$
\begin{aligned}
W(k+1)= & W(k-d) \\
& +\eta U_{1}(k) M_{2}(k-d) \omega(k-d) I^{T}(k-d)
\end{aligned}
$$

ただし， $M_{1}, M_{2}$ は対角行列であり，その対角要素は以下 のように表わされる。

$$
\begin{aligned}
& M_{1 i i}(k)=f\left(\sum_{j=1}^{\nu} W_{i j}(k) I_{j}(k) /\left(\sum_{j=1}^{\nu} W_{i j}(k) I_{j}(k)\right)\right. \\
& {\left[\text { ただし }\left(\sum_{j=1}^{\nu} W_{i j}(k) I_{j}(k)\right)=0 \text { のとき, } M_{1 i i}(k)=0\right]}
\end{aligned}
$$

$$
M_{2 i i}(k)=f^{\prime}\left(\sum_{j=1}^{\nu} W_{i j}(k) I_{j}(k)\right)
$$

式中 $f$ は (32)式の非線形飽和関数である.（35)式の定義 より

$$
\left|M_{1 i i}(k)\right| \leqq 1, \quad\left|M_{2 i i}(k)\right| \leqq 1
$$

(33)，(34) 式より， $U_{1}^{2}(k)$ が微小のとき次式が成立する.

$$
\begin{aligned}
& \omega^{T}(k+1) W(k+1) \\
& \fallingdotseq \omega^{T}(k-d) W(k-d) \\
&+\eta U_{1}(k)\left\{\omega^{T}(k-d) M_{2}(k-d) \omega(k-d)\right. \\
& I^{T}(k-d) \\
&\left.+I^{T}(k-d) W^{T}(k-d) M_{1}(k-d) W(k-d)\right\} \\
&= \omega^{T}(k-d) W(k-d)+\eta K_{P} \zeta^{T}(k-d) \xi_{N}(k-d)
\end{aligned}
$$

$$
\begin{aligned}
\xi_{N}(k)= & I(k) I^{T}(k)\left\{\omega^{T}(k) M_{2}(k-d) \omega(k) \Gamma\right. \\
& \left.+W^{T}(k) M_{1}(k-d) W(k)\right\}
\end{aligned}
$$

(38)，（39）式より，線形のニューラルネットワークを用 いたときと同様のパラメー夕誤差に関する以下の差分方 程式を得る。

$$
\zeta^{T}(k+1) \fallingdotseq \zeta^{T}(k-d)\left\{\Gamma-\eta K_{P} G_{0} \xi_{N}(k-d)\right\}
$$

よって, 線形の場合と同様の議論により $\xi_{N}(k-d)$ の最 大の固有值を $\lambda_{0 N}$ とすると安定条件は以下のように表わ される.

$$
0 \leqq \eta K_{P} G_{0} \lambda_{0 N} \leqq 2
$$

(41) 式に示したように非線形飽和関数の影響をマトリク ス $M_{1}, M_{2}$ を用いることにより表現し，非線形ニューラ ルネットワークを用いたときの安定条件を線形の場合と 同様の手法により議論することができることがわかる.

\section{8. ま と め}

ニューラルネットを用いた適応型フィードフォワード フィードバックコントローラを離散時間系を対象に設計 した。特に, 川人らのコントローラは 2 次連続時間系の
MR モデルを対象としているのに対し，本コントローラ は離散時間系の ARMA モデルを対象として設計を行っ ている。また，ニューラルネットワークおよびプラント が線形の場合についてパラメー夕誤差の安定条件を検討 することによりフィードバックループのゲインがニュー ラルネットワークの重みの学習の安定性に与える影響を 明らかにした。また，提案したコントローラについて 2 次プラントを対象としたシミュレーションにより本コン トローラが実現可能であり，非線形要素抒よび寄生要素 を含むブラントに対しても有効であることを明らかにし た。さらに，先の線形時の安定解析を非線形ニューラル ネットワークへ拡㲀する一手法について考察した.

本報告をまとめるに当たり御指導頂いた NTT フィールドシステム研究開発センタ涌井所長並びに川瀬 部長に深く感謝致します。

\section{参 考 文 献}

1) C. W. Anderson: Learning To Control On Inverted Pendulum Using Neural Networks, IEEE Control System Magazine, 9-3, 31/37 (1989)

2) H. Lui, T. Iberal and G. A. Bekey: Neural Network Architecture For Robot Hand, IEEE Control System Magazine, 9-3, 38/43 (1989)

3) K. M. Passino, M. A. Sarori and P. J. Antsaklis: Neu ral Computing For Numeric to Symbolic Conversion In Control Systems, IEEE Control System Magazine, 9 $-3,44 / 52(1989)$

4) R. Eckmiller: Neural Nets For Sensory and Motor Trajectories, IEEE Control System Magazine, 9-3, 53/ 59 (1989)

5) M. Kuperstein and J. Rubinstein: Implementation of an Adaptive Neural Controller for Sensory-Motor Coordination, IEEE Control System Magazine, 9-3, 25/30 (1989)

6) K. S. Narendra and K. Parthctsarathy : Identification and Control of Dynamics Systems Using Neural Net works, IEEE Transaction on Neural Networks, 1-1, 4/ 27 (1990)

7) Miller, Sutton and Werbos: Neural Network For Control, MIT Press (1990)

8) D. Psaltis, A. Sidereris and A.A. Yamamura: A Multilayered Neural Network Controller, IEEE Control System Magazine, 8-2, 17/22 (1988)

9) D. Psaltis, A: Siders and A. Yamamura: Neural Controller, Proceedings of 1987 IEEE International Conference on Neural Networks, IV, 551/558, San Diego (1987)

10）山田, 薮田：ダイレクトコントローラに関する一考察, 計 測自動制御学会論文集, 27-7, 784/791 (1991)

11) M. Kawato, Y. Uno, M. Isobe and R. Suzuki : Hierar chical Neural Network Model For Voluntary Movement With Application To Robot, IEEE Control System Magazine, 8-2, 8/16 (1988)

12) M. Kawato, Y. Uno, M. Isobe and R. Suzuki: A Hierarchical Model for Voluntary Movement and its Application to Robotics, Proceedings of 1987 IEEE International Conference on Neural Networks, IV, 573/582 (1987) 
13) Rumelhart, McClelland and the PDP Research Group : Parallel Distributed Processing, The MIT Press (1988)

14) T. Yabuta and T. Yamada: Possibility of Neural Network Controller for Robot Manipulators, 1990 IEEE International Conference on Robotics and Automation, Cincinati, 1686/1691 (1990)

15) T. Yamada and T. Yabuta: Nonlinear Neural Network For Dynamic System, IECON '90 (16th Annual Conference Of IEEE Industrial Electronics Society), Pacific Grove, California, U.S.A., 1244/1249 (1990)

16）㨶田, 福田: 神経回路モデルによるロボットの力制御, JRSJ, 7-1, 47/51 (1989)

17) T. Yamada, T. Yabuta and T. Takahashi: Remarks On An Adaptive Type Self-tuning Controller Using: Neural Networks, IECON '91 (International Conference On Industrial Electronics, Control and Instrument), Kobe, Japan, 1389/1394 (1991)

18）市川邦彦編：適応制御, 昭晃堂

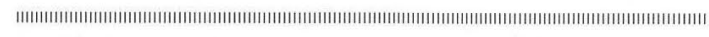

$$
\text { [著 者 紹介] }
$$

山田孝 行 (正会員)

1983 年, 九州大学工学部電気工学科卒 業, 85 年同大学大学院修士課程修了. 同年 日本電信電話 (株) 入社. 以来, マニピュレー 夕の制御および保守用センサの研究に従 事. 近年, ニューラルネットワークなどを 用いた制御系の研究に従事. 日本ロボット 学会, 電気学会などの会員.

\section{藪 田 哲 郎 (正会員)}

(Vol. 30, No. 7 参照)

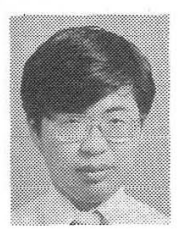

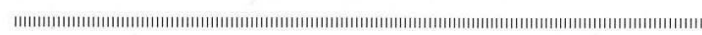

